'N TOEKOMSTIGE PERSPEKTIEF OP GRONDWETLIKE STABILITEIT

ISSN 1727-3781

2010 VOLUME 13 No 2 


\section{'N TOEKOMSTIGE PERSPEKTIEF OP GRONDWETLIKE STABILITEIT ${ }^{\star}$}

\section{FW de Klerk ${ }^{* *}$}

2 Februarie volgende jaar sal die twintigste herdenking wees van die begin van die proses van transformasie, wat gelei het tot die instelling van ons huidige nie-rassige grondwetlike demokrasie. Die vorige jaar, toe ek die koukus van die Nasionale Party toegespreek het ná my onverwagte verkiesing tot leier van die party, het ek klem gelê op die noodsaaklikheid om 'n kwantumsprong te neem om weg te breek van die politieke en ekonomiese doodloopstraat waarin ons onsself bevind het. Die oorweldigende reaksie was "spring FW, spring!".

En so het ons, twintig jaar gelede, 'n berekende geloofsprong gedoen. Ons het dit onwaarskynlik beskou dat daar ooit weer sulke gunstige omstandighede sou wees vir 'n skikking:

- ná die val van die Berlynse Muur was globale Kommunisme in wanorde gedompel;

- die Suid-Afrikaanse Kommunistiese Party - wat gedurende die 1980s feitlik al die setels in die ANC se Nasionale Uitvoerende Komitee beheer het was in volle vlug;

- ná die mislukking van die 1984-1987 offensief om Suid-Afrika onregeerbaar te maak, het die ANC uiteindelik aanvaar dat daar nie 'n revolusionêre resultaat sou wees nie;

- alle partye het aanvaar dat voortgesette toename in konflik die ekonomie en enige hoop op 'n verenigde toekoms sou verwoes; en

- $\quad$ in die verkiesings van September 1989 het die wit kieserskorps 'n duidelike mandaat aan die Nasionale Party gegee vir omvangryke hervorming en onderhandelings.

\footnotetext{
* Toespraak tydens die agtste FW de Klerk lesing, Noordwes-Universiteit, Potchefstroomkampus, op 12 Oktober 2009.

** $\quad$ Frederik Willem de Klerk, voormalige Staatspresident van die Republiek van Suid-Afrika..
} 
Nooit weer sou die balans van magte so gunstig wees vir 'n regverdige onderhandelde skikking nie. Desnieteenstaande het ons nie onderhandelings blindelings aangepak nie:

- Informele en uitgebreide verkennende gesprekke met die ANC en met Nelson Mandela het reeds plaasgevind.

- Ons was vol vertroue dat ons in staat sou wees om 'n grondwet te onderhandel wat die billike regte van alle Suid-Afrikaners kon beskerm - 'n grondwet wat die bekommernisse van diegene wat baie gehad het om te verloor, sowel as die aspirasies van diegene wat baie gehad het om te bereik, kon akkommodeer.

- Dít alles het plaasgevind binne 'n groeiende globale situasie waar ' $n$ grondwetlike demokrasie en vryemarkbeginsels die botoon gevoer het. Die werklikheid was dat geen substantiewe ekonomie dit kon bekostig om die groeiende konsensus oor hierdie beginsels te ignoreer nie. Daardie lande - soos Zimbabwe, Kuba en NoordKorea wat dit wel ignoreer het - het'n enorme prys betaal.

- Daar was ook aanvaarding dat die noodsaak om eenheid in ons diverse bevolking te bevorder, noodwendig beperkings sou plaas op enige nuwe regering wat te voorskyn sou kom uit die onderhandelsproses.

Die onderhandelinge het ' $n$ hoogtepunt bereik op 21 Desember 1993 met die aanvaarding van die Tussentydse Grondwet, ${ }^{1}$ wat die grondslag vir SuidAfrika se eerste universele demokratiese verkiesing in April 1994 gevorm het. Dit het ook die raamwerk daargestel vir die opstel en aanvaarding van ' $n$ finale grondwet deur die behoorlik verkose Parlement wat terselfdertyd gedien het as ' $n$ Grondwetlike Vergadering. Belangrikste van alles was dat die sogenaamde finale Grondwet sou moes voldoen aan 35 grondwetlike beginsels, wat deel was van die 1993 Grondwet. Die Grondwetlike Vergadering het daarna die finale Grondwet van die Republiek van Suid-

1 Grondwet van die Republiek van Suid-Afrika, 200 van 1993 (hierna 1993 Grondwet). $16 / 204$ 
Afrika, $1996^{2}$ behoorlik opgestel, dit in 1996 aanvaar en voorgelê aan die pas ingestelde Grondwetlike Hof vir sertifisering. Eers op 4 Februarie 1997, nadat die Hof ten volle oortuig was daarvan dat die Grondwet in alle opsigte voldoen het aan die 35 grondwetlike beginsels, het die nuwe Grondwet van toepassing geword.

Sedertdien het die Grondwet op daadwerklike wyse gedien as die grondslag van ons nuwe samelewing:

- $\quad$ dit verwoord die waardes waarop die nuwe Suid-Afrika gefundeer is;

- dit gee uitdrukking aan die transformasie doelwitte van menswaardigheid, gelykheid en sosiale geregtigheid waarna ons almal moet streef;

- $\quad$ dit sit die regte waarop al ons burgers geregtig is, uiteen; en

- dit maak voorsiening vir ware demokratiese beginsels vir die organisering van die Staat, insluitend ' $n$ uitvoerende gesag wat verantwoordbaar is aan ' $n$ demokraties verkose wetgewende gesag, 'n onafhanklike regbank wat waghou oor die Grondwet, en die oppergesag van die reg en die Handves van Regte. ${ }^{3}$

Desondanks was die Grondwet 'n groot historiese kompromie. Geen party het alles behaal wat hulle wou hê nie - maar alle partye was in staat om hul minimum vereistes te verseker. Sommiges wou 'n unitêre staat hê; ander ' $n$ federasie; sommiges wou onbeheerste mag gehad het om eiendom te onteien; ander was diep bekommerd oor die toekoms van hul huise en besighede. Sommige wou 'n enkele Suid-Afrikaanse identiteit hê; ander het aangedring daarop dat ons ryk kulturele en taaldiversiteit behoue moet bly. Oor al hierdie kritieke kwessies kon ons kompromieë bereik, baie waarvan dikwels fyn gebalanseerd was.

2 Hierna die Grondwet.

3 Hfst 2 van die Grondwet. 
Vir Suid-Afrika is ons Grondwet dus baie meer as 'n blote handboek oor hoe ons die meganismes van demokrasie of die beskerming van basiese menseregte moet bestuur. Die bewoording van die aanhef is gerig daarop om die verdelings van die verlede te heel en om 'n samelewing te vestig wat gebaseer is op demokratiese waardes, sosiale geregtigheid en fundamentele menseregte.

Inderdaad is die Grondwet die onontbeerlike grondslag van ons nasionale eenheid en bied dit ons beste en blywende hoop vir voortgesette vryheid, voorspoed en stabiliteit. Vir al hierdie redes durf ons niemand toelaat om dit te ondermyn of dit te bedreig nie. En tog staan die Grondwet onder bedreiging, en wel op sewe verskillende fronte.

Die eerste bedreiging lê in die moontlikheid dat die Parlement dalk wettiglik die Grondwet sal wysig. In terme van Artikel 74 mag die Parlement enige bepaling in die Handves van Regte en in die res van die Grondwet wysig, met ' $n$ tweederdemeerderheid in beide die Nasionale Vergadering en die Nasionale Raad van Provinsies, asook met die ondersteuning van ses van die nege provinsies. Dit is egter belangrik om daarop te let dat die Parlement die fundamentele bepalings in Artikel 1 slegs mag wysig met ' $n$ 75\% meerderheid. Met ander woorde, die Parlement het 'n baie beperkte vermoë om enige bepaling te wysig op 'n wyse wat sou lei tot die ondermyning van die basiese instellings van ons demokrasie; die oppergesag van die reg; en die waardes van nie-rassigheid, menswaardigheid, gelykheid en die bevordering van menseregte en vryhede.

Toegegee, die Regering het min geneentheid getoon om wesenlike wysigings van die Grondwet voor te stel - ten spyte daarvan dat dit al jare lank die nodige tweederdemeerderheid gehad het om dit te doen. Die uitsonderings is die Veertiende Grondwetlike Wysigingswetsontwerp ${ }^{4}$ en die Sewentiende Grondwetlike Wysigingswetsontwerp, ${ }^{5}$ wat tans voor die Parlement dien.

$4 \quad$ Constitution Fourteenth Amendment Bill GK 520 in SK 31013 van 8 Mei 2008.

5 Constitution Seventeenth Amendment Bill GK 869 in SK 32311 van 17 Junie 2009. 
Die Veertiende Grondwetlike Wysigingswetsontwerp, wat ingedien is teen die einde van 2005, sou sleutel aspekte van die onafhanklikheid van die regbank wel ernstig ondermyn. Gelukkig het die Regering die Wetsontwerp die daaropvolgende jaar teruggetrek, nadat dit sterk en vasberade teenstand gekry het van regsgeleerdes en kommentators van regoor die politieke spektrum.

Die tweede uitsondering is die Sewentiende Grondwetlike Wysigingswetsontwerp, wat verreikende implikasies het vir die toekomstige outonomie en lewensvatbaarheid van plaaslike bestuur. Onder die voorwendsel van ' $n$ inisiatief om ' $n$ meer effektiewe verspreiding van elektrisiteit te verseker, sal die Wetsontwerp in effek die Regering op nasionale vlak die mag gee om in te meng in ' $n$ wye reeks munisipale funksies. Deur dit te doen sal die Regering nie alleen een van die belangrikste kompromieë in die Grondwet ondermyn nie. Dit sal ook 'n presedent skep wat die outonomie van provinsies mag raak.

Die tweede bedreiging is geleë in die erosie van grondwetlike beginsels deur gewone wetgewing. In hierdie proses word grondwetlike regte in toenemende mate ingekort deur bepalings wat weggesteek word in gewone wetgewing. So byvoorbeeld sou die Onteieningswetsontwerp, ${ }^{6}$ wat verlede jaar aan die Parlement voorgelê is, die rol van die howe in die vasstelling van regverdige vergoeding vir onteinde eiendom, ernstig beperk. Sodoende sou dit die grondwetlike reg op billike administratiewe optrede en toegang tot die howe ernstig inkort. Gelukkig is die Wetsontwerp onttrek.

Daar was soortgelyke probleme verlede jaar met die Wysigingswet op die Nasionale Vervolgingsgesag ${ }^{7}$ en die Wysigingswet op die Suid-Afrikaanse Polisiediens, ${ }^{8}$ waarkragtens die Skerpioene ontbind is en 'n nuwe eenheid binne die Suid-Afrikaanse Polisiediens gestig is om ernstige misdaad te

Expropriation Bill GK 440 in SK 30963 van 11 April 2008.

7 National Prosecuting Authority Amendment Act 56 van 2008.

8 South African Police Services Amendment Act 57 van 2008. 
beveg. Kritici glo dat dié wetgewing die grondwetlik gewaarborgde onafhanklikheid van die Nasionale Vervolgingsgesag ondermyn het en dit ontneem het van sy grondwetlike mag om "enige funksies te verrig wat in verband met die instel van strafregtelike verrigtinge nodig is".

Op dieselfde wyse ondermyn die onlangs aanvaarde Wysigingswet op Films en Publikasies ${ }^{9}$ aspekte van die grondwetlik gewaarborgde reg op vryheid van spraak. In die opinie van die kritici wyk dit af van die versigtig bewoorde teks van die Grondwet se definisie van ontoelaatbare kommunikasie; dit is onaanvaarbaar vaag; dit skep ongelyke omstandighede vir die media wat behoort aan erkende media organisasies en dié wat nie; en dit vereis van sommige media, die onmoontlike taak om hul materiaal aan sensors voor te lê vóór dit gepubliseer word.

Die derde bedreiging vir die Grondwet spruit uit verwaarlosing deur die uitvoerende gesag. In terme van hierdie praktyk steur die uitvoerende gesag hom eenvoudig nie aan daardie elemente van die Grondwet waarvan hy nie hou nie. Dit is veral duidelik uit die manier waarop die Grondwet se voorsiening vir taal- en kultuurregte stelselmatig geïgnoreer word sedert 1994.

Die Grondwet stel die volgende vereistes met betrekking tot taal:

- $\quad$ Dit erken ons elf amptelike tale.

- Dit vereis dat die staat spesiale stappe neem om ons inheemse tale te ontwikkel.

- Dit vereis dat regerings op nasionale en provinsiale vlak twee amptelike tale moet gebruik.

- Dit verklaar dat munisipaliteite die taalvoorkeure van inwoners in ag moet neem.

- Dit bepaal dat die nasionale en provinsiale regerings hul gebruik van amptelike tale moet reguleer en monitor.

9 Films and Publications Amendment Act 3 van 2009. 
- $\quad$ Dit vereis dat alle amptelike tale gelykheid in aansien moet geniet en gelyk behandel moet word.

- Dit verklaar dat alle Suid-Afrikaners die reg het om onderwys in openbare onderwysinstellings te ontvang in die taal of tale van hul keuse, waar daardie onderwys redelikerwys doenlik is.

Ongelukkig word feitlik elkeen van hierdie bepalings geïgnoreer of verwater sedert die aanvaarding van die Grondwet in 1996:

- In toenemende mate het ons 'n enkele de facto amptelike taal - en dit is Engels.

- Die Regering maak nie voldoende gebruik van twee amptelike tale nie.

- Ons tale geniet nie gelykheid in aansien nie - en word nie gelyk behandel nie.

- Bloedweinig is tot dusver gedoen om ons inheemse tale te ontwikkel.

- Enkelmedium Afrikaanse skole is onder druk, en daar is ernstige kommer oor die behoud van Afrikaans as die primêre taal van onderrig by Stellenbosch Universiteit.

Die vierde bedreiging vir die Grondwet spruit uit 'n gebrek aan kapasiteit in die uitvoerende gesag. Op baie terreine blyk dit dat die Regering nie in staat is om belangrike regte op effektiewe wyse te verseker nie, vanweë die krisis wat dit ervaar rondom dienslewering.

Die ongelukkige realiteit is dat:

- buitensporige geweldsmisdaad te dikwels mense ontneem van hul reg op lewe, hul reg om vry te wees van alle vorms van geweld, en hul reg op eiendom;

- die reg op gelykheid veronagsaam is, deur die feit dat ons ná vyftien jaar steeds een van die mees ongelyke samelewings in die wêreld is 
- die staat het nie gepaste wetgewing en ander maatreëls ingestel om diegene wat benadeel is deur onregverdige diskriminasie, te beskerm en bevorder nie; die gepaste maatreëls is nie ongebalanseerde regstellende aksie nie, maar behoorlike onderwys, effektiewe dienslewering en werkskepping;

- die regte van kinders nie voldoende respekteer word nie - soos geïllustreer word deur hoë vlakke van mishandeling en verwaarlosing, die bestaan van te veel straatkinders en te veel kinders wat aan die hoof van huishoudings staan;

- $\quad$ die reg op basiese onderwys ernstig ingeperk is deur die mislukking om behoorlike onderwys te verskaf; en

- te veel mense het in die praktyk nie voldoende toegang tot howe of ' $n$ verhoor sonder onredelike vertraging nie.

Die verskaffing van effektiewe onderwys, polisiëring en gesondheidsdienste is 'n belangrike vereiste vir die verwesenliking van grondwetlike regte.

Die vyfde bedreiging het sy ontstaan in die moontlikheid dat die Grondwet toenemend deur die howe interpreteer mag word om die uitvoerende gesag of 'n enkele deel van ons samelewing te bevoordeel. Ek moet klem daarop lê dat dit nog nie gebeur het nie. Die howe het, in die geheel, uitsprake gelewer wat onafhanklik en onpartydig is. Die nuwe Hoofregter het sy toewyding tot die handhawing van die onafhanklikheid van die regbank en van die Grondwet oortuigend oorgedra.

Ons kan egter nie die beroep ignoreer wat gedoen is deur die ANC se Nasionale Uitvoerende Komitee in 2005 om "die kollektiewe denkwyse van die regbank" ... "in ooreenstemming te bring met die visie en aspirasies van die miljoene wat deelgeneem het aan die struggle om ons land te bevry van oorheersing deur die wit minderheid" nie. Gegewe hierdie benadering, bestaan die bedreiging steeds dat die uitvoerende gesag toenemend sal probeer om te verseker dat regters, wat hulle met hierdie standpunt vereenselwig, op die regbank aangestel word. 
Dit is heeltemal aanvaarbaar in Suid-Afrika - soos in ander lande met gerespekteerde regterlike tradisies - dat verkose regerings kan en moet verseker dat die regbank by bly by veranderende openbare waardes en houdings. Daar is egter grense vir die toelaatbare politieke evolusie van die regbank - veral in multikulturele gemeenskappe soos ons s'n.

Die konvensie waarop demokrasie rus is dat vrae rondom politieke mag nie beslis moet word deur verwoestende en verdelende konflik nie, maar deur vrye en regverdige verkiesings. Die noodsaaklike afleiding hiervan is dat wenners van verkiesings die burger- en politieke regte van die verloorders moet respekteer. Hierdie proses moet gereguleer word deur grondwette en handveste van regte en moet bereg word deur regverdige en onafhanklike howe. In 'n sin word grondwette hoofsaaklik opgestel om die belange van minderhede en individue wat nie mag besit nie te beskerm - aangesien meerderhede gewoonlik hul beheer van staatsmag kan gebruik om hul eie belange te beskerm. In die geval van Suid-Afrika is dit veral belangrik dat die politieke evolusie van die regbank nie toegelaat word om die sorgvuldig onderhandelde grondwetlike konsensus, waarop ons nuwe samelewing gebaseer is, te ondermyn nie.

Baie grondwetlike regte is versigtig gebalanseerd met kontraregte. Daar is ' $n$ reg op eiendom - maar daar is ook 'n reg op grondhervorming; daar is vryheid van diskriminasie - maar daar is ook voorsiening vir wetgewende en ander maatreëls om diegene wat deur onregverdige diskriminasie benadeel is, te bevorder. Daar is ' $n$ reg op onderwys in die taal of tale van jou keuse - maar dit moet doenbaar, billik en nie-rassig wees. Daar is 'n reg om jou eie taal te gebruik en eie kultuur te beoefen - maar nie op só 'n wyse dat dit ander se regte sal ondermyn nie. Indien die howe voortdurend uitsprake sou lewer ten gunste van slegs een kant van hierdie balans, sal dit die sorgvuldig onderhandelde kompromieë vernietig - en daarmee saam ook die vooruitsigte van nasionale eenheid en stabiliteit. 
Die sesde bedreiging vir die Grondwet spruit uit die vooruitsig van politieke ondergrawing. Die les van die ANC se $52^{\text {ste }}$ Nasionale Konferensie by Polokwane was dat mag volgens hulle siening nie lê by die Grondwet of die Parlement, die uitvoerende gesag of die regbank nie. Dit lê, volgens die linkervleuel van die ANC, in die hande van watter groep ook al beheer kan neem van die meerderheidsparty in die Parlement. Dit is omdat Artikel 47(3)(c) van die Grondwet stipuleer dat lede van die Parlement hul lidmaatskap van die Parlement verloor indien die party waaraan hul behoort, hul party lidmaatskap ophef. Ons parlementêre verteenwoordigers is gevolglik nie primêr verantwoordelik aan die kieserskorps nie - maar aan die base van hul onderskeie partye.

By Polokwane het die vermoë van faksies, wat gekant was teen President Mbeki, om net $10 \%$ van die stemme om te swaai, 'n algehele skuif in nasionale politieke mag tot gevolg gehad. Die nuwe leierskap van die party wat nie deur die publiek verkies is nie - het besluit wat die wetgewende program van die Parlement moet wees, skryf voor wie aangestel moet word in belangrike politieke poste en het uiteindelik die president afgedank.

Dit is gevolglik net so belangrik om die magsverhoudinge in die leierskap van die regerende party dop te hou, as wat dit is om die breër politieke toneel in die nasionale arena te monitor. Ons moet spesifiek die veranderende verhoudings binne in die ANC/SAKP/COSATU-Alliansie monitor. In die verband moet ons die volgende in gedagte hou:

- COSATU steun die SAKP se politieke visie. Daarom, van 'n politieke perspektief, moet dit eintlik die ANC/SAKP-Alliansie wees. Beide die SAKP en COSATU wy hulle daaraan toe om "MarxismeLeninisme as 'n instrument van wetenskaplike ondersoek" uit te bou om "te soek na antwoorde in die kontemporêre wêreld".

- $\quad$ COSATU en die SAKP ondersteun die ANC se doktrine van die Nasionale Demokratiese Revolusie - maar slegs as ' $n$ grondslag vir verdere vordering tot die behaling van hul medium-termyn visie. 
Hierdie visie is om "'n werkersklas hegemonie in die staat in sy diversiteit te vestig en in alle ander areas van mag". Hul langtermyn visie is om 'Sosialisme' te vestig, dit wil sê, 'n volwaardige Kommunistiese staat.

- Die SAKP het ' $n$ beroep gedoen op die "hersamestelling van die Alliansie" deur middel van die daarstelling van 'n Alliansie Politieke Raad om "toesig te hou oor breë politieke kwessies". Die ANC en COSATU sal elkeen ses lede op die raad hê en die SAKP ' $n$ beskeie vyf.

- Die SAKP het tagtig lede in die vorige Parlement gehad wat verkies is op die ANC se lys. Dit was twintig persent van totale verteenwoordiging, ten spyte van die feit dat meningspeilings daarop wys dat die SAKP en COSATU gesamentlik nie meer as agt persent van die stemme sou kon verwerf nie. Desnieteenstaande dring die SAKP daarop aan dat sy lede wat deur middel van die ANC se lys verkies is, se primêre lojaliteit by die SAKP moet lê.

- Die SAKP het die idee om aan toekomstige verkiesings as ' $n$ afsonderlike party deel te neem, laat vaar en meen dat "alhoewel verkiesings belangrik is, daar nie ' $n$ voorafbepaalde enkele roete vir die werkersklas is om mag te hegemoniseer nie". Met ander woorde, hulle beplan om mag langs ander weë te bekom.

- By die Twaalfde Kongres in Julie 2007 het die SAKP, met goedkeuring, die lank staande opdrag van die Kommunistiese Party van die Sowjet Unie aangehaal, naamlik dat die SAKP moet fokus op "die sistematiese ontwikkeling van die leierskap van die werkers en die Kommunistiese Party in hierdie organisasie" - dit is die ANC.

In die afgelope paar weke het ons gesien dat COSATU en die SAKP ' $n$ hewige aanval geloods het op minister Trevor Manuel. Dit lyk of hulle glo dat sy onlangs gepubliseerde Groenskrif oor Nasionale Strategiese Beplanning ${ }^{10}$ ' $n$ voorteken is van ' $n$ terugkeer na die breë ekonomiese beleidsrigtings van 
President Mbeki. Die uitkoms van hierdie stryd, wat al hoe meer sigbaar word, sal wys waar die swaartepunt in die ANC nou lê.

COSATU en die SAKP maak geen geheim van hul voorneme om die grondslag te lê vir werkersklas hegemonie in die staat en in alle magsentrums nie. Die doelwit is die instelling van 'n Marxisties-Leninistiese staat. Nodeloos om te sê, enige sodanige skuif sal 'n rampspoedige slag wees - nie net vir ons Grondwet en ons demokrasie nie, maar ook vir ons ekonomie en enige vooruitsig op vrede en stabiliteit.

Die finale bedreiging vir ons Grondwet is moontlik die gevaarlikste van almal. Dit is ons eie apatie. Dit is ons traagheid om ons Grondwet aktief te ondersteun en aanspraak te maak op die regte wat dit waarborg. Ons almal gaan bloot voort met ons daaglikse lewens; ons vat ons kinders skool toe; ons dra by tot die ekonomie in ons kantore en fabrieke; ons onthaal ons vriende; en ons gaan op vakansie. Selde stop ons om te bedink dat feitlik alles wat ons doen, alles wat ons besit, alles waarna ons streef, saamhang met die handhawing van ons Grondwet en die vryhede en regte wat dit waarborg. Ons is geneig om die Grondwet te beskou as iets op die kantlyn van ons lewens, iets waaraan ons slegs aandag hoef te gee wanneer dit dringend nodig raak.

Ons moet ontslae raak van hierdie houding. Ons toekomstige geluk en voorspoed en die toekomstige sekuriteit van ons kinders is direk afhanklik van die handhawing van ons Grondwet. Dit is nie iets wat mens sommer maar net kan toevertrou aan hierdie of daardie politieke party, of hierdie of daardie burgerregte organisasie nie. Vir boosheid om te floreer is dit genoeg dat goeie mense niks doen nie - apaties is.

Ek doen ' $n$ beroep op almal om in die volgende maande, in aanloop tot die twintigste herdenking van 2 Februarie 1990, daadwerklike stappe te doen om die Grondwet te ondersteun. Weet wat u regte is; eis dit op en dring daarop aan dat die eweneens geldige regte van alle ander Suid-Afrikaners 
gerespekteer word; ondersteun organisasies soos die Sentrum vir Grondwetlike Regte onder die vleuels van die FW de Klerk Stigting; maak die Grondwet 'n sleutel faktor in u denke en u lewe - want, glo my, dit is werklik belangrik.

Ondersteuning vir die Grondwet beteken nie dat $\mathrm{u}$ maar net iets doen vir 'n goeie saak nie: dit is die mees gepaste beskerming van eie belang waaraan ek kan dink. Ons is bereid om goeie geld te betaal om ons huise, ons karre, ons gesondheid en ons lewens te verseker. Wat is ons bereid om te doen om ons toekomstige vryheid, vrede en voorspoed te verseker?

Ten spyte van die waarskuwings wat ek gegee het oor die bedreigings wat ons Grondwet in die oë staar, bly ek steeds 'n optimis. Ek is vol vertroue dat baie mense in die ANC leierskap deel in talle van die bekommernisse wat ek vanaand na vore gebring het. $E k$ is seker daarvan dat die oorgrote meerderheid in al ons gemeenskappe die Grondwet ondersteun. Wat nou nodig is, is dat ons moet hande vat, dat ons saam moet fees vier oor ons suksesse sedert 1990 en dat ons moet saamwerk in aanvaarding van die uitdagings waarvoor ons staan.

\section{Bibliografie}

\section{Lys van wetgewing}

Grondwet van die Republiek van Suid-Afrika, 1996

Films and Publications Amendment Act 3 van 2009

Grondwet van die Republiek van Suid-Afrika, 200 van 1993

National Prosecuting Authority Amendment Act 56 van 2008

South African Police Services Amendment Act 57 van 2008

\section{Lys van staatspublikasies}

Constitution Fourteenth Amendment Bill GK 520 in SK 31013 van 8 Mei 2008 
Constitution Seventeenth Amendment Bill GK 869 in SK 32311 van 17 Junie 2009

Expropriation Bill GK 440 in SK 30963 van 11 April 2008

South Africa Presidency "National Strategic Planning" (Green Paper) September 2009 